\title{
Working paper \\ Who are the most active and influential politicians and parties on Twitter? The case of Germany ${ }^{1}$
}

\author{
Paul C. Bauer \\ Mannheim Centre for European Social Research \\ First version: 2 December, 2019 \\ This version: 23 June, 2021 \\ Download: https://osf.io/y8hpk \\ Paper prepared for presentation at the Virtual European Political Science Association Annual \\ Conference, 24-25 June 2021 \\ Ideas? Feedback? mail@paulcbauer.eu
}

\begin{abstract}
Political elites increasingly use Twitter as an instrument to spread their views. Yet, it is hard to come by up-to-date descriptive statistics that would tell us how active and influential politicians, as well as, parties are on Twitter. With the election looming (26th of September 2021) in Germany, the present study attempts to provide a descriptive, comparative and up-todate overview of Twitter activity/influence across politicians and parties. It analyzes around 125,000 recent tweets, published by around 550 active politicians Among other things the study reveals that the share of Twitter users is lowest among members of the CDU/CSU, while there is strong variation in terms of activity (tweets) across and within parties, as well as across time. Regarding influence, well-known members of centrist parties dominate follower statistics, however, members of the populist left and right dominate in terms of retweets. Finally, AfD politicians get more retweets per tweet than members of other parties.
\end{abstract}

Keywords: twitter, political elites, politicians, activity, influence, power. 


\section{Introduction}

While the internet was initially hailed as a medium of democratization, early-on scholars also warned of its potentially negative influence (Hindman 2008; Morozov 2011). Today, social media has become a standard medium for communication and campaigning and represents a new arena in which politicians compete for attention and influence. ${ }^{2}$ Citizens use social media to gather information about political issues as well as to inform their political decisions and preferences. And, importantly, politicians' social media posts spill over to other platforms, e.g., Twitter posts are increasingly used as sources by mainstream media (Moon and Hadley 2014; Paulussen and Harder 2014). At times journalists cite a series of tweets of different actors to illustrate a debate. This increases the outreach of such platforms and thereby their relevance. Recent use by high profile politicians such as Trump has only strengthened this trend. In the wake of these realities research on the role of social media in politics has "exploded" with reviews summarizing the state of the art and corresponding controversial debates (e.g., Jungherr 2016; Joshua A Tucker et al. 2017). Everyone agrees, however, that we need to understand how these platforms revolutionize politics and the present study asks How active and influential are politicians and parties on Twitter in Germany?

In pursuing this question I contribute to current scholarship in several ways. First, I provides evidence from Germany. Roth, Peters, and Seruga (2014) published a notable study comparing elected politicians' Twitter use between Australia, Germany and the U.S. The authors found strong differences in terms of politicians' twitter activity across these countries. Generally, however, social media studies of political elites mostly focus on the U.S. This focus is somewhat natural as use of the respective platforms has developed most strongly in the U.S. and is politically most relevant as a consequence (Bastos and Mercea 2019; Hindman and Barash 2018). In the present study I provide evidence for the case of Germany and I compare activity and influence both across individual politicians as well as parties (cf. Quinlan et al. 2018a; Jürgens and Jungherr 2015; Thimm, Einspänner-Pflock, and Anastasiadis 2016).

Second, I provide up-to-date evidence. Social media data is a running target. Both the users of such platforms change but also how they use such platforms. With the rise of the AfD of Germany which entered the German parliament in 2017, a new set of politicians joined the broader population of elected politicians on social media. However, also the very landscape of social media platforms and the rules according to which they operate change. Think of the "recent" rise of Instagram or the landmark decision to ban political ads from the Twitter platform (McGregor 2019). Any sound discussion of the role of those platforms in politics requires up-to-date evidence.

Third, besides these broader points I would like to add descriptive evidence speaking to a recent debate on the power imbalance between parties/politicians in the social media arena. In the case of Germany it was recently argued that some parties, e.g., the AfD, are more dominant in the social media arena in terms of activity and influence (Diehl, Lehberger, Müller, and Seibt 2019; Serrano, Shahrezaye, Papakyriakopoulos, and Hegelich 2019). The present study further scrutinizes whether such imbalances really exist both in terms of activity and influence.

Fourth, the present study should also be regarded as a methodological contribution. It is purely descriptive and it does not investigate why certain actors are more active or influential on social media. It merely explores if they are. While the former research aim is important, I have the impression that insightful comparative description of social media data across politicians and parties is a methodological challenge that warrants attention on its own. One challenge lies in coming up with meaningful graphs that allow for a sound comparison. Another challenge lies in the discussion of currently used measures of activity and influence.

I proceed as follows: Section 2 provides and overview of Twitter as a network platform and discusses how we can conceptualize and measure activity as well as influence. Section 3 presents the design, data, and measures. Section 4 summarizes the results. Section 5 provides a conclusion and suggestions for future research.

\footnotetext{
${ }^{2}$ By now various official parliamentary websites advertise politicians' social media accounts and social media is used instrumentally show support or opposition to certain issues (Syal and Sabbagh 2020).
} 


\section{Theory \& evidence: Measuring activity and influence}

In the wake of the digital revolution we are moving from a few-to-many structure to a many-tomany structure of political communication (Joshua A. Tucker et al. 2017). ${ }^{3}$ For politicians social media provides a direct line to their constituents, certainly to their followers but also others once their content spreads. One mechanism is that mass media journalists increasingly refer to politicians' social media posts which extends their reach. Despite the increasing role of social media in politics we know that not all politician's have an equal presence on the respective platforms.

Social media activity and influence vary over time and can be measured through various indicators. Twitter data is probably best conceived of as a set of several networks. Strongly simplified the underlying technology is a bunch of websites (user web sites) that are connected to each other through various links. One network contains the user websites/profiles that have a unique ID (these we would be the nodes of one network we could discuss). One network layer that connects these nodes are the followership ties, with directed ties that indicate who follows whom. If there is directed tie from person A to B, B may in principle see A's posts on his/her own Twitter website. Such posts/tweets can be conceived of as the parcels that travel around this network. ${ }^{4}$ Twitter posts (tweets) are little websites in themselves and also have a unique ID. In principle, they also represent nodes in a network that we could study since they are connected through, e.g., through retweets or replies.

Social media activity and its sound measurement requires a discussion of all actions an individual can undertake on the platform, i.e., which buttons they can push. To start, politicians can decide whether to join Twitter or not. Some still refrain from using Twitter, some joined the platform early on and others later (below we call this account creation and prevalence). Once participating, Twitter users can decide whether to follow others or not. ${ }^{5}$ Users can tweet, retweet a tweet, reply to a tweet, like a tweet, send a tweet via a direct message, add a tweet to bookmarks and copy the link to a tweet. When they tweet they can add an image, a gif, a link, or a survey and they can also report tweets. Users can also mute or block someone or unfollow them. Importantly, anyone - even non-members - can embed tweets on websites. Activity then refers to the frequency of such actions and naturally the frequency may refer to different time intervals. At the end researchers have to decide which of these actions can be regarded as politically relevant. ${ }^{6}$

Social media influence is the more difficult concept to define and measure. In part, the question here is - parallel to that very question on the level of citizens (Hindman 2008) - whether politicians are equal in the extent to which their views are considered online. Departing from a politician A's account, one metric would be the number of followers, also called the node in-degree in the network (Weng, Lim, Jiang, and He 2010, 262). ${ }^{7}$ Subsequently, one can enhance the follower-metric by taking into account follower characteristics. For instance, two politicians A and B may have the same number of followers, however, A's followers may be more influential themselves. Influence is also related to how other people (followers and non-followers) on the platform react to

\footnotetext{
${ }^{3}$ The actual social media networks between politicians and citizens potentially still reflect a few-to-many structure. ${ }^{4}$ Importantly, users can also be exposed to tweets by people they are not following, either outside of the platform, or because they are forwarded by someone to which they have a tie. Sometimes they may also be exposed to someone's tweets in another way, e.g., because Twitter suggests to follow them showing some of their tweets.

${ }^{5}$ Importantly, we can differentiate between active data generation, e.g., tweeting, and passive data generation, e.g., transmitting the geolocation to Google without knowing it.

${ }^{6}$ Importantly, patterns of activity can be used to identify, e.g., whether the social media account (or a set of accounts) is operated by a computer program (Hindman and Barash 2018) as discussed in this insightful visualization: https: //www. knightf oundation.org /features/misinfo.

${ }^{7}$ However, in-degrees do not necessarily reflect the concept of influence (see Weng et al. 2010, 262; Brin and Page 1998; Kleinberg 2011)
} 
A's actions. A classic metric of reaction is the number of retweets of A's tweets which can both be retweets by followers and non-followers. While one could take the sum of retweets across all of A's tweets, a better metric is probably A's sum of retweets divided by the A's sum of tweets (for certain time periods). Another measure of influence measure is the number of times a politician A's account is addressed in others' tweets (e.g., through replies).

Empirical evidence both in terms of social media activity and social media influence using the above metrics (and more sophisticated metrics) is still scarce. The table below provides a non-complete overview of various studies that investigated Twitter activity and influence of politicians, sometimes as a subset of broader analyses. ${ }^{8}$ Importantly, evidence is restricted to certain populations (mostly to the U.S. context) and to certain time periods ${ }^{9}$, i.e., a lot of the research focuses on campaign periods. However, as the digital arena changes, i.e., as new platforms emerge, new players join and existing players adapt their strategies, so do the incentives to both become active and influential on social media platforms. In other words, the ever changing landscape requires up-to-date data, statistics and graphs.

\begin{tabular}{|c|c|c|c|c|c|}
\hline Study & Measures & User Sample & Sample size & $\begin{array}{c}\text { Level of } \\
\text { comparison }\end{array}$ & $\begin{array}{l}\text { Time } \\
\text { period }\end{array}$ \\
\hline $\begin{array}{l}\text { Roth et al. } \\
(2014)\end{array}$ & $\begin{array}{l}\text { ACTIVITY: Account creation date; Top } \\
3 \text { trending topics, i.e., words most used } \\
\text { by politicians in their tweets; Mentioned } \\
\text { Half-Life (MHL), i.e., the number of days } \\
\text { after which } 50 \% \text { of the lifetime mentions } \\
\text { have been posted; Followers + Retweets; }\end{array}$ & $\begin{array}{l}\text { US: House of } \\
\text { Representatives, } \\
\text { Senate; DE: } \\
\text { Bundestag, } \\
\text { Bundesrat; AU: } \\
\text { House of } \\
\text { Representatives, } \\
\text { Senate; }\end{array}$ & $\begin{array}{l}881 \text { accounts; } 891737 \\
\text { tweets }\end{array}$ & Tweets; Politicians & $\begin{array}{l}\sim 2007- \\
-2012\end{array}$ \\
\hline $\begin{array}{l}\text { Larsson and } \\
\text { Kalsnes (2014) }\end{array}$ & $\begin{array}{l}\text { Account presence; Average number of } \\
\text { tweets per day; Activity index: Number } \\
\text { of tweets divided by account age in } \\
\text { number of days }\end{array}$ & $\begin{array}{l}\text { SE: Parliament; NO: } \\
\text { Parliament }\end{array}$ & 577 accounts & Politicians & $\begin{array}{l}\text {-May } \\
2013\end{array}$ \\
\hline $\begin{array}{l}\text { Nulty, } \\
\text { Theocharis, } \\
\text { Popa, Parnet, } \\
\text { and Benoit } \\
(2016)\end{array}$ & $\begin{array}{l}\text { ACTIVITY: Account presence; Tweet } \\
\text { volume, type, content, sentiment; } \\
\text { Hashtags; }\end{array}$ & $\begin{array}{l}\text { EU: Candidates in } \\
2014 \text { EP election }\end{array}$ & $\begin{array}{l}2750 / 3180 \text { accounts } \\
\text { out of } 15353 \\
\text { identified MEP } \\
\text { candidates; } 441301 \\
\text { tweets }\end{array}$ & Tweets;Politicians & $\begin{array}{l}\text { May } 3 \text { - } \\
\text { June } 1 \\
2014, \text { last } \\
3 \text { weeks of } \\
\text { electoral } \\
\text { campaign }\end{array}$ \\
\hline $\begin{array}{l}\text { Cha, Haddadi, } \\
\text { Benevenuto, } \\
\text { and Gummadi } \\
(2010)\end{array}$ & $\begin{array}{l}\text { INFLUENCE: in-degree (number of } \\
\text { followers), retweets (number of retweets } \\
\text { containing the users' name), mentions } \\
\text { (degree of engagement with others) }\end{array}$ & Normal twitter users & $\begin{array}{l}6189636 \text { user } \\
\text { accounts; } 1755925520 \\
\text { tweets }\end{array}$ & users; tweets & - Aug 2009 \\
\hline $\begin{array}{l}\text { Suh, Hong, } \\
\text { Pirolli, and Chi } \\
(2010)\end{array}$ & INFLUENCE: Retweets & Normal twitter users & $\begin{array}{l}10000+73884474 \\
\text { tweets }\end{array}$ & Tweets, Users & $\begin{array}{l}\text { Jan } 18- \\
\text { Mar } 8 \\
2010 \\
\text { (among } \\
\text { others) }\end{array}$ \\
\hline $\begin{array}{l}\text { Kwak, Lee, } \\
\text { Park, and } \\
\text { Moon }(2010)\end{array}$ & INFLUENCE: Followers, Retweets & Normal twitter users & $\begin{array}{l}41.7 \text { million user } \\
\text { accounts, } 1.47 \text { billion } \\
\text { social relations, } 4262 \\
\text { trending topics, and } \\
106 \text { million tweets }\end{array}$ & Tweets, Users & $\begin{array}{l}\text { User } \\
\text { profile } \\
\text { collection: } \\
\text { Jul } 6 \text { - Jul } \\
312009\end{array}$ \\
\hline $\begin{array}{l}\text { Weng et al. } \\
(2010)\end{array}$ & $\begin{array}{l}\text { INFLUENCE: Topic-sensitive page rank } \\
\text { that takes into account followership, link } \\
\text { structure (tweets) and similarity of topics } \\
\text { between the one followed and follower }\end{array}$ & $\begin{array}{l}\text { Top-Singapore-based } \\
\text { twitterers }+ \\
\text { followers and friends }\end{array}$ & $\begin{array}{l}996 \text { user accounts }+ \\
\text { their followers and } \\
\text { friends }\end{array}$ & Tweets, Users & $\begin{array}{l}\text {-April } \\
2009\end{array}$ \\
\hline $\begin{array}{l}\text { Bakshy, } \\
\text { Hofman, } \\
\text { Mason, and } \\
\text { Watts (2011) }\end{array}$ & $\begin{array}{l}\text { INFLUENCE: Measure that takes into } \\
\text { account both followership, amount of } \\
\text { tweets and similarity of topics between } \\
\text { the one followed and follower }\end{array}$ & $\begin{array}{l}\text { Normal twitter users } \\
\text { (bit.ly posters) }\end{array}$ & $\begin{array}{l}74 \text { million diffusion } \\
\text { events; } 1.6 \mathrm{M} \text { users } \\
\text { (seeders of events); } \\
46 \mathrm{M} \text { followers }(1.7 \mathrm{~B} \\
\text { edges) }\end{array}$ & Tweets, Users & $\begin{array}{l}\text { Sep } 13- \\
\text { Nov } 15 \\
2009\end{array}$ \\
\hline
\end{tabular}

Quinlan et al. 


\begin{tabular}{|c|c|c|c|c|c|}
\hline$(2018 b)$ & ACTIVITY: Account presence & $\begin{array}{l}\text { Candidates of of the } \\
\text { German Federal Election } \\
2013\end{array}$ & $\begin{array}{l}\sim 1721 \text { users accounts among } 2776 \\
\text { candidates }\end{array}$ & Users & $2013 / 2015$ \\
\hline $\begin{array}{l}\text { Hemphill, } \\
\text { Otterbacher, } \\
\text { and Shapiro } \\
(2013)\end{array}$ & ACTIVITY: Account presence & $\begin{array}{l}\text { Members of the US } \\
\text { congress }\end{array}$ & $\begin{array}{l}380 \text { user accounts of members of } \\
\text { Congress' accounts during winter of } \\
2012 ; 30373 \text { tweets }\end{array}$ & Users & $\begin{array}{l}\text { Aug } 2011 \\
\text { - Feb } 2012\end{array}$ \\
\hline $\begin{array}{l}\text { Golbeck, } \\
\text { Grimes, and } \\
\text { Rogers }(2010)\end{array}$ & ACTIVITY: Tweet content & $\begin{array}{l}\text { Members of the US } \\
\text { congress and Senate }\end{array}$ & $\begin{array}{l}159 \text { user accounts of members of } \\
\text { Congress and Senate; } 6475 \text { tweets }\end{array}$ & Users & $\begin{array}{l}\text { Feb 2009; } \\
\text { May 2009; } \\
\text { Sep } 2009\end{array}$ \\
\hline $\begin{array}{l}\text { Petrarca, } \\
\text { Tyrberg, and } \\
\text { Wilson (2019) }\end{array}$ & ACTIVITY: Tweet content & $\begin{array}{l}\text { Members of the Swedish } \\
\text { parliament }\end{array}$ & $\begin{array}{l}229 \text { user accounts out of the } 349 \\
\text { elected parliamentarians elected in } \\
2018 ; 21 \text { million tweets collected over } \\
83 \text { days }\end{array}$ & Politicians & $\begin{array}{l}\text { Jun } 20 \text { to } \\
\text { Sep } 10 \\
2018\end{array}$ \\
\hline $\begin{array}{l}\text { Gelman, } \\
\text { Wilson, and } \\
\text { Petrarca } \\
(2019)\end{array}$ & $\begin{array}{l}\text { CONTENT: Tweet tone } \\
\text { (positive, negative) and content } \\
\text { (issue, aggressive attack, } \\
\text { mobilization) }\end{array}$ & $\begin{array}{l}\text { Candidates for } 2019 \text { U.S. } \\
\text { midterm elections } \\
\text { (Governor's, House, } \\
\text { Senate races) }\end{array}$ & $\begin{array}{l}887 \text { user accounts of candidates; } \\
210914 \text { tweets sent by these } \\
\text { candidates }\end{array}$ & $\begin{array}{l}\text { tweets, } \\
\text { politicians }\end{array}$ & $\begin{array}{l}\text { Sep } 14- \\
\text { Election } \\
\text { Day, }\end{array}$ \\
\hline \multicolumn{6}{|l|}{$12 \mathrm{Nov}$} \\
\hline $\begin{array}{l}\text { Evans, } \\
\text { Cordova, and } \\
\text { Sipole }(2014)\end{array}$ & $\begin{array}{l}\text { ACTIVITY: Account presence; } \\
\text { CONTENT: Tweet style } \\
\text { (Personal, Mobilization etc.) }\end{array}$ & $\begin{array}{l}\text { US House candidates in } \\
2012 \text { election }\end{array}$ & $\begin{array}{l}1119 \text { user accounts of candidates; } \\
67119 \text { tweets sent by these candidates }\end{array}$ & $\begin{array}{l}\text { tweets, } \\
\text { politicians, } \\
\text { parties }\end{array}$ & $\begin{array}{l}2 \text { months } \\
\text { before } \\
\text { Nov } 6 \text {, } \\
2012\end{array}$ \\
\hline
\end{tabular}

\section{Methods: Design, data, measures and models}

Our population of interest comprises politicians that are currently members of the German Bundestag. Out of 709 politicians in our sample we identified 558 that have a Twitter account $(79 \%)$. The election is looming in Germany, hence, the relevance of up-to-date statistics on German politicians. The Twitter account data I am using was updated in June 2021 and either scraped or collected manually within the project Intra-Party Politics and European Multiparty Governments. ${ }^{10}$ Importantly, Twitter account data is a running target as politicians may join or leave Twitter as well as change their accounts at any time. ${ }^{11}$.

Subsequently, I collect tweets posted by those accounts and update this data on a daily basis. Currently, the Twitter API allows to scrape an account's last 3200 tweets. If a politician posted more then 3200 tweets it can happen that we don't capture the user's whole post history. However, since the empirical focus is the last months in the present study this is less relevant.

Currently, there are 152863 tweets in the database we analyze for this study. In the analyses below we sometimes restrict this data to the last 24 hours (1303 tweets, 2021-06-21 22:08:05 - 2021-06-22 21:59:20 UTC), the last 7 days (7078 tweets, 2021-06-15 22:01:39 - 2021-06-22 21:59:20 UTC) or the last 3 months (102611 tweets, 2021-03-21 23:09:35 - 2021-06-22 23:45:49 UTC). These tweets are then aggregated and analyzed on the level of politicians or parties for different time periods. The oldest tweet in the dataset is from 2021-03-01 00:05:46 and the most recent from 2021-06-23 01:45:49.

\footnotetext{
${ }^{10}$ The project is led by Alejandro Ecker collaborating with Michael Imre at the MZES: https://www.mzes .uni-mannheim.de/d7/en /projects/intra-party-politics-and-european-multiparty-governments.

${ }^{11}$ Unfortunately, we have moved beyond the early times when user numbers where still in the tens of millions and access was much less restricted so that researchers were still able to collect the data of the entire Twitter platform (e.g., Kwak et al. 2010; Suh et al. 2010)
} 


\section{Empirical results}

\subsection{Activity: Account creation and prevalence}

We identified 558 that have a Twitter account (79\%).

Since Twitter provides the date of creation for each account, we can analyze account creation over time. Figure 4.1, Plot 1 depicts the number of accounts created per month starting with the creation date of the first account. Figure 4.1, Plot 2 graphs the cumulative number of accounts. In our sample the first account that was started on 15 May, 2008. Generally, Plot 2 emphasizes the steady increase Twitter accounts among the politicians in our sample. Account creation happened rather continuously across time. Naturally, whether and when politicians start Twitter accounts are outcomes that can be explained with various theories (e.g., Hemphill et al. 2013).

$$
\begin{array}{ll}
\text { Institution } \multimap & \begin{array}{l}
\text { German Bundestag } \\
\text { (Accounts=554, Seats=709) }
\end{array}
\end{array}
$$

Plot 1

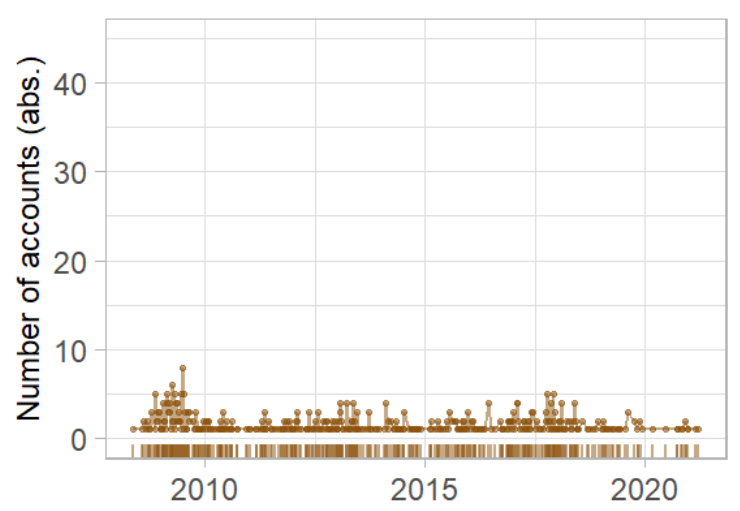

Plot 2

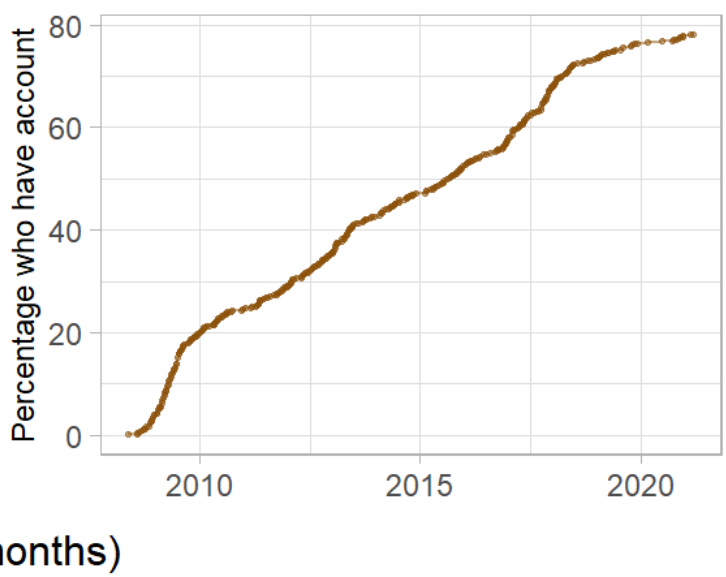

Figure 4.1: Account creation over time

Figure 4.2 visualizes the absolute number of politicians with and without accounts across parties, as well as the relative percentage. In Germany the CDU/CSU is one of the parties with the fewest accounts in terms of relative share which can probably be explained by the fact that CDU parliamentarians are older on average. 


\section{German Bundestag}

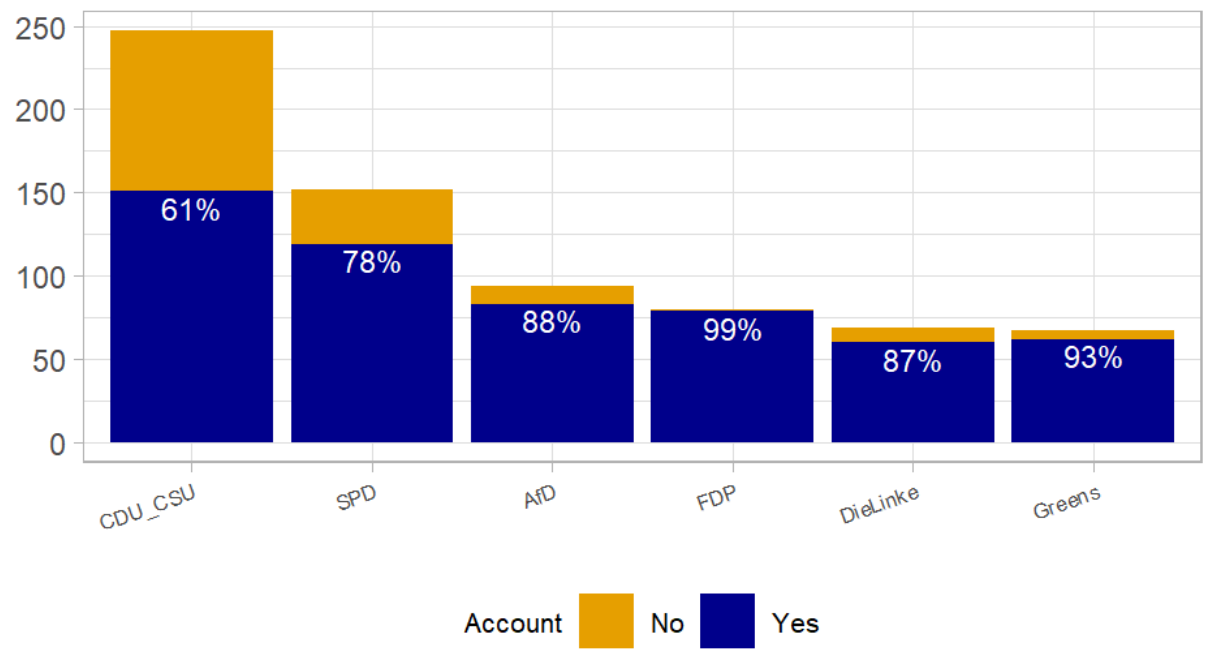

Figure 4.2: Number of Twitter accounts across parties/party groups 


\subsection{Activity: Tweet/post frequency}

In Section 2 we summarized what actions Twitter users have available to them. Obviously posting a tweet is the central one, hence, an important metric of activity. The amount of tweets politicians (members of the German Bundestag) produce is quite stunning as can be seen in Figure 4.3. Figure 4.3 (Plot 1) provides a first overview of the number of tweets for a longer time period. Importantly, this includes original tweets, retweets and replies to other tweets. The points are the actual averages (the line is a smoothing curve). Figure 4.3 (Plot 2) normalizes the number showing the per account per week amount of tweets. To start, the graphs uncovers a lot of variation across time (here the time scale are weeks). Variation in Twitter activity across time is related the occurrence of significant political events, e.g., debates in the parliaments or campaigns. Moreover, the parties do not seem to lief all the far apart, with the AfD seemingly publishing the lowest number of tweets both overall (Plot 1) and per account (Plot 2).
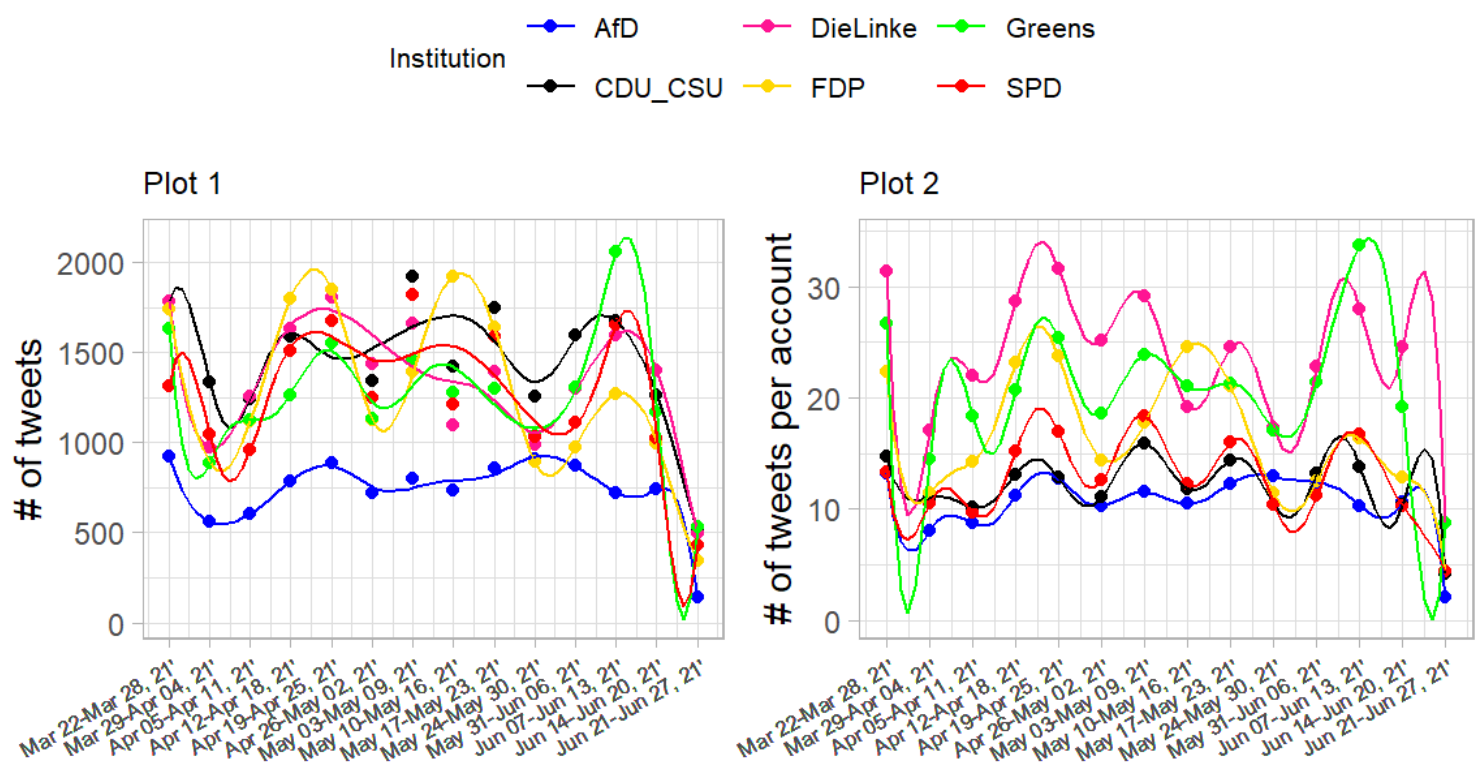

Weeks (CET)

Figure 4.3: Parties: Number of tweets per week

Figure 4.4 visualizes the per account, per week sum of tweets on the level of politicians, colored according to parties. In addition, averages and variance on the party level have been added. Hence, the graph provides insights both into individual politicians as well as parties. Figure 4.4 illustrates the strong variation that underlies those tweet frequencies both across politicians and parties (this includes tweets, retweets and replies). 


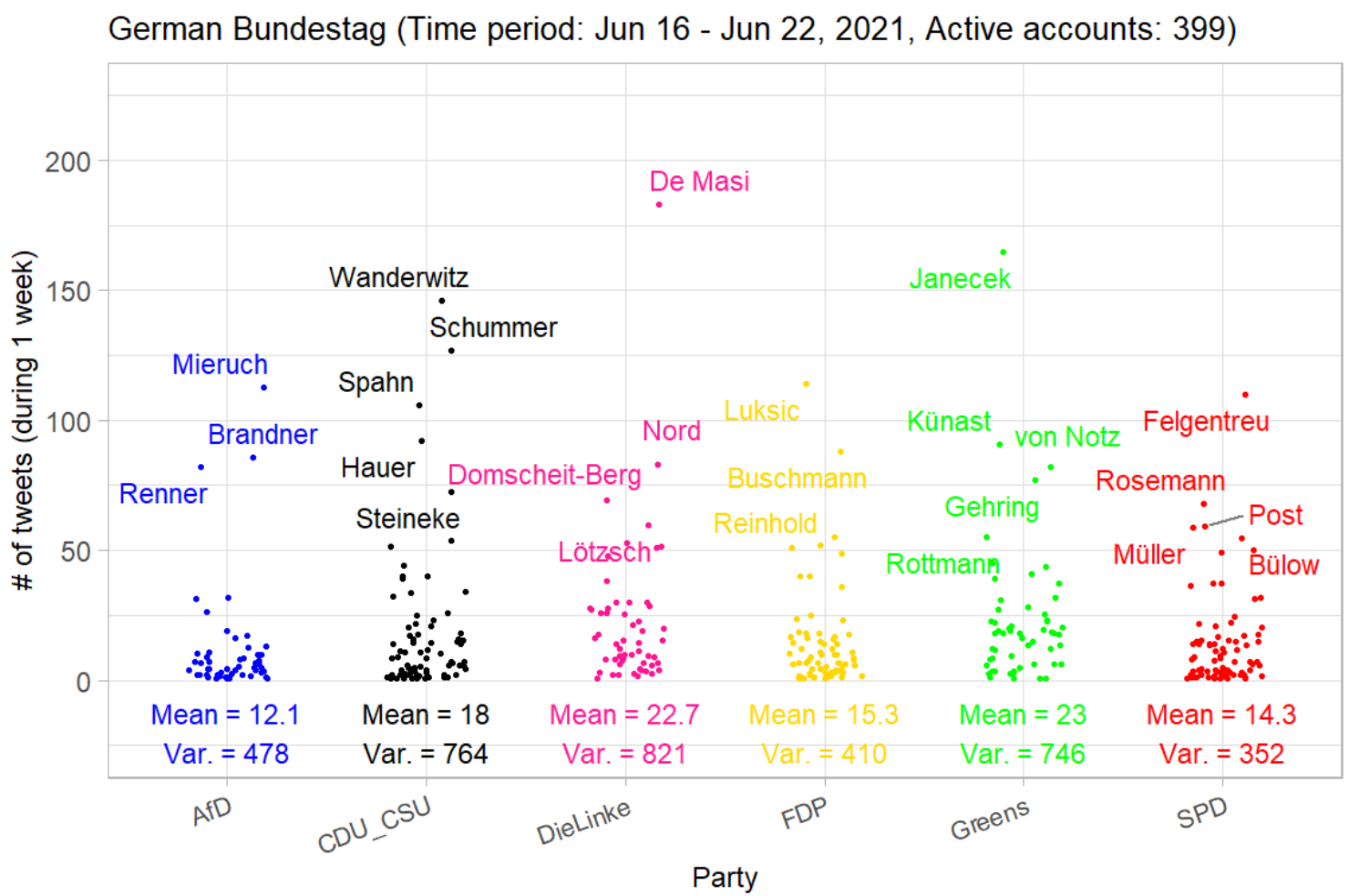

Figure 4.4: Number of tweets per week across accounts across parties

Many parties have "outlier politicians", i.e., politicians that are much more active than there colleagues. For instance, Beutin from DieLinke is the most active politician. For each party, Figure 4.4 also provides the mean and the variance across their members (the ones that have accounts). We can see that in terms of the per week number of tweets per politician, that DieLinke and the Greens have the highest averages. But importantly, this average covers a strong within-party variation between politicians.

\subsection{Influence: Followers \& retweets}

Analog to the analyses of activity above I explore influence both for individual politicians as well as for parties. In their investigation of influence Roth et al. (2014) analyze data from Australia, Germany and the U.S. They contrast the number of followers with the number of retweets across politicians. Here I replicate those analyses for Germany, albeit I allow for a comparison across parties (colored). Accordingly, Figure 4.5 (and Figure 4.6 without Lauterbach) visualizes the number of followers and retweets for each politician whereby party affiliation is indicated by the color (and label). Importantly, for this graph I only count retweets of tweets that originated from a politician's account, i.e., I exclude a politicians' tweets that were simply retweets of others' posts. In doing so I focus on the last three months as not to give an advantage to older accounts. 


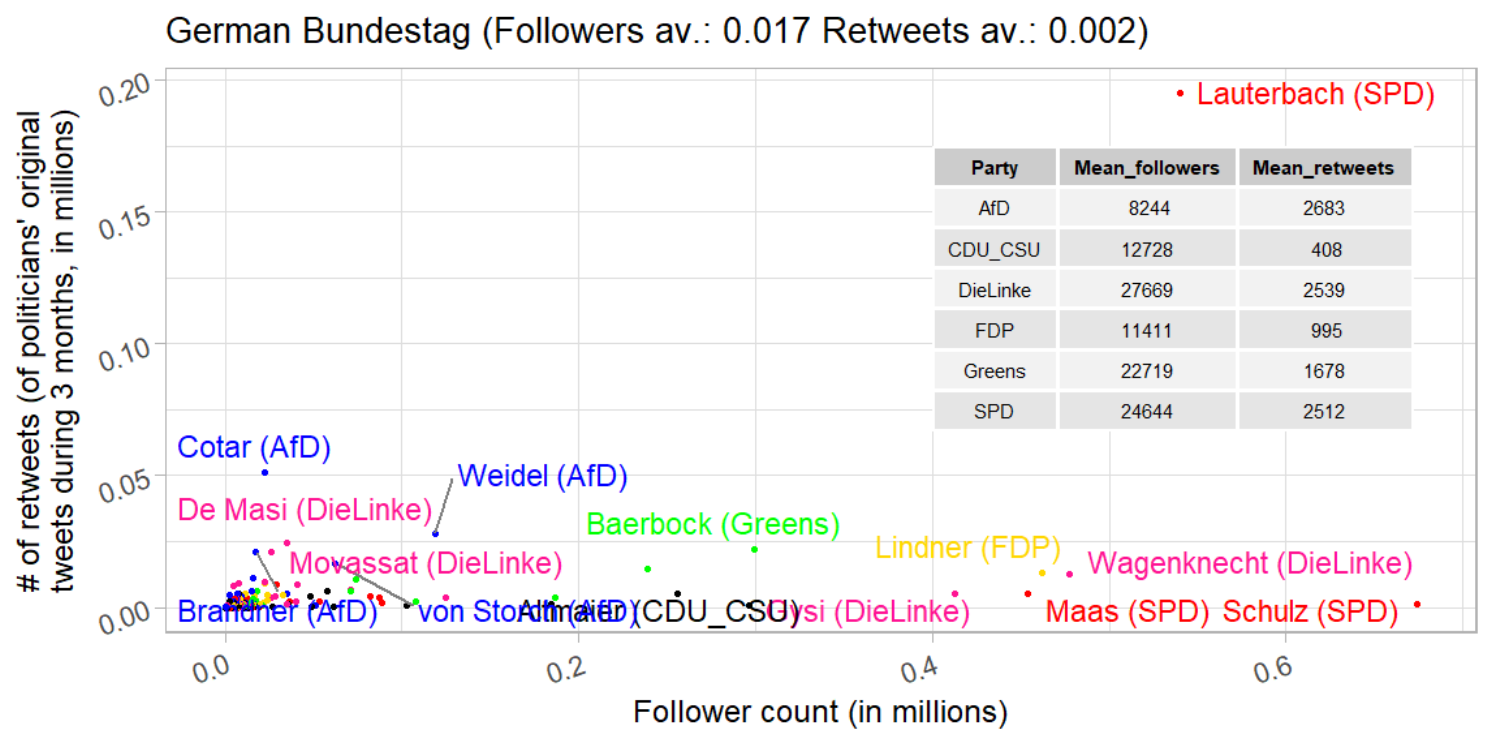

Figure 4.5: Influence in terms of followers and retweets across politicians

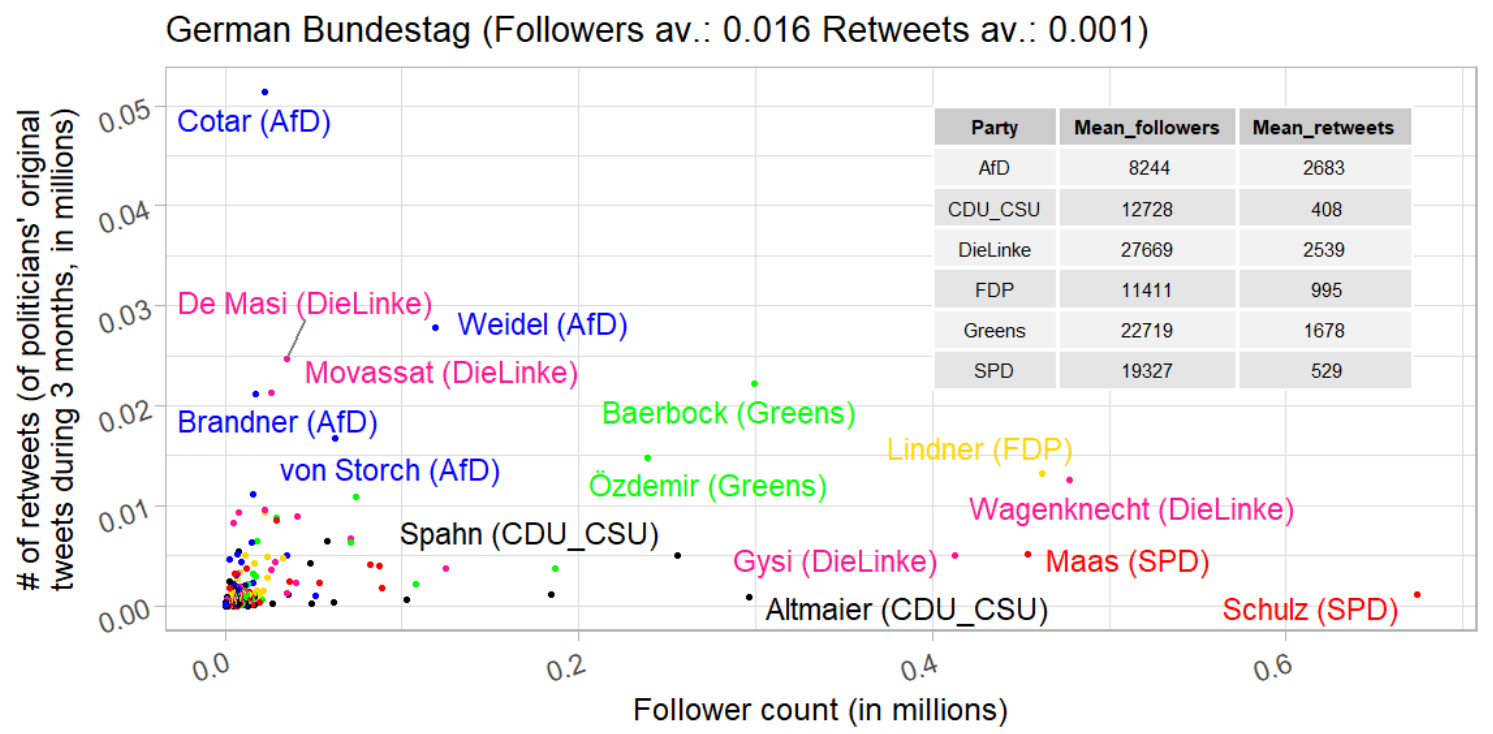

Figure 4.6: Influence in terms of followers and retweets across politicians (without Lauterbach)

Just as for activity the variation in terms of influence (measured through retweets and followers) is quite strong. First, in the wake of the Corona crisis Lauterbach has massively grown his influence in terms of followers and retweets. Thereby, he stands in contrast to popular politicians such as Schulz (SPD) or Wagenknecht (DieLinke) who have a lot of followers but fare worse on the retweet metric, as well as politicians Cotar (AfD), Weidel (AfD) and De Masi (DieLinke) who have high values on the retweet metric but less so on the follower metric. Lauterbach's rise in influence came about with the Corona crisis (Lauterbach is an expert in Health Policy). Second, Figure 4.6 illustrates that the leading AfD politicians (and politicians of DieLinke) wield strong influence measured in terms of retweets despite the fact that they do not necessarily dominate the follower metric. The idea that follower influence does not necessarily come with retweet influence is reflected by a the moderate correlation of 0.33 in our data. Importantly, this descriptive result raises the question of what makes the posts of these politicians so popular. Besides, the fact that they may produce more engaging content it could also be related to follower characteristics (more active followers, more bots etc.). 
Figure 4.7 visualizes the number of retweets per tweet per week for the last 3 months on the party level, i.e., tells us whether certain parties (that is their members) are retweeted more for each tweet its members publish. Only politicians' original tweets are taken into account (no retweets). I excluded Lauterbach again because of his outsized influence on those statistics (Figure 5.1 in the appendix include his data). While Figure 4.3 seems to show that AfD politicians are not necessarily more active on Twitter (they do not tweet more), and Figure ?? illustrates that AfD politicians do not necessarily have more followers, Figure 4.7 illustrates that AfD politicians get more retweets per tweet. To me the fact that the AfD outpaces other parties is an interesting puzzle. There are various factors that may be at play here. It is possible that AfD politicians produce content that is more likely to be retweeted (e.g., more catchy, more emotional). It's also possible that the followership of AfD politicians is more active, i.e., that AfD followers tend to retweet more than followers of other parties. It's also possible that there are more bots sharing AfD tweets. Some tentative arguments are made in a recent Spiegel Article which focuses on Facebook data and is entitled "How the German Right Wing Dominates Social Media ${ }^{12 "}$ (Diehl et al. 2019). However, we still lack a systematic analysis that would test different explanations against each other.

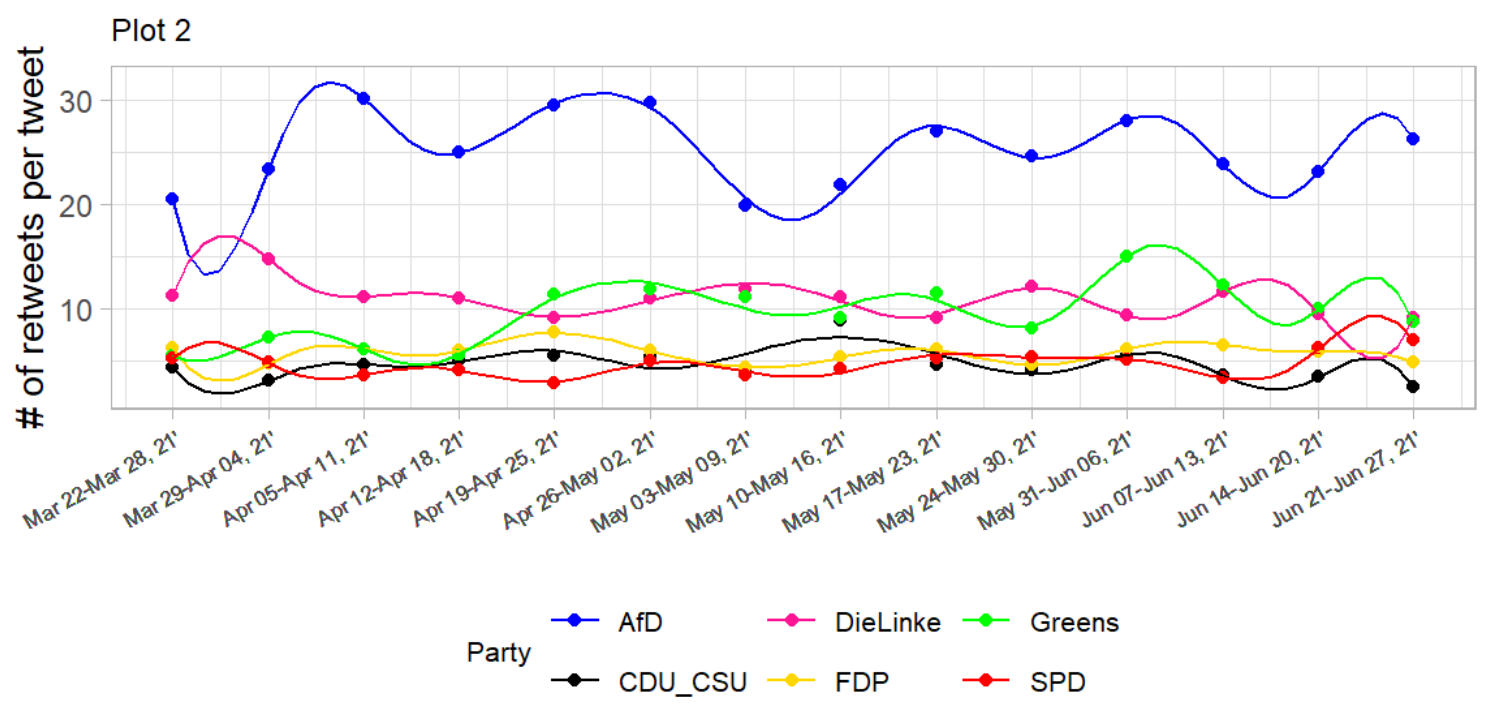

Figure 4.7: Retweets per week across all party member accounts (without Lauterbach)

\section{Conclusion}

The present study explores the Twitter activity and influence of 558 German politicians (out of 709) that are members of the German Bundestag. Thereby, it provides descriptive evidence both on the level of politicians as well as on the level of parties.

I find that the prevalence of Twitter accounts is surprisingly high across most parties, e.g., reaching $99 \%$ for the FDP. With $61 \%$ the CDU/CSU has the least members with a Twitter account (cf. Figure 4.2). Account creation happened almost linearly across time for the politicians in our dataset (with slightly stronger developments around the federal elections) (cf. Figure 4.1).

Visualizing the number of tweets per week as a metric of Twitter activity across parties (cf. Figure 4.3) solely seems to show that AfD politicians churn out fewer tweets than members of other parties. However, once we move to a specific, recent, one-week time period in Figure 4.4 activity seems to be lower for SPD politicians than for AfD politicians. In other words, such statistics strongly depend on the time period we study. In addition, Figure 4.4 illustrates the strong variation that underlies such party averages. 
Exploring Twitter influence measured through simple metrics such as followers and retweets reveals some interesting patterns. Generally, the evidence supports previous findings that the twitter graph is right-skewed in terms of followers and retweets. In every party there are a few politicians that yield comparatively large influence on Twitter (cf. 4.6). Interestingly, however, a high number of followers does not necessarily come with influence in terms of retweets. Germany is an interesting example insofar the politicians of more centrist parties dominate in terms of followers, while newer politicians of the populist right-wing party AfD (but also of the Left party) dominate in terms of retweets. As discussed above various explanations may lurk behind this phenomenon (tweet content, bots etc.). Finally, a retweets per tweet metric (cf. Figure 4.7) reveals that AfD politicians are seemingly more successful in spreading their content for every tweet they invest, at least they get more shares per tweet on average. While politicians from both the AfD and the DieLinke top the graph in terms of the sheer number of retweets (cf. the y-scale in Figure 4.6), AfD members seem to be more effective in doing so. As suggested above different factors may lie at the origin of this advantage (e.g., follower characteristics, social media professionality etc.). And, there is evidence that Twitter is still inhabited by a large number of "politically motivated" bots (Howard, Bolsover, Kollanyi, Bradshaw, and others 2017; Howard and Kollanyi 2016; Neudert et al. 2017).

Our findings should be interpreted with various limitations in mind. First, the metrics of activity and influence we study here are fairly basic. For instance, while a politician may get a high number of retweets, these don't necessarily reflect that his or her posts where received positively. Oftentimes the most retweeted tweets are the most polarizing ones. Hence, future analyses should explore the quality of retweets. As they are studied here retweets potentially reflect attention by others be it positive or negative. Second, accounts can not be equated with politicians. In a recent (unpublished survey) we found that many politicians operate their Twitter accounts together with their team. As a consequence, what we could have thought of as a politician's activity, thus, becomes a team's activity (as such the size of a politician's team could explain the quantity of activity). Third, we have no information on how politicians' tweets enter their followers "tweet menu", i.e., how the algorithm decides what followers get to see on their feed and what not. Naturally, this has implications insofar followers can only pay attention to and share what they see in the first place. Explaining influence on Twitter is, thus, hampered by the inability to study Twitter's secret algorithm sauce and its potential objectives such as engagement.

Should we be concerned about the variation or inequality we find here? To some extent yes. Politicians' and parties' mass media communication is (or has been) regulated in the past (e.g., Brazell 2008). In contrast, some of the social media posts we can now read on a weekly basis by some of the more extreme, elected politicians would not have made it through the mass media filter 20 years ago. At the same time the inequality we see here in terms of attention could in part be driven by the fact that attention is awarded to more extreme, polarizing and emotionally engaging content. In addition, as the digital arena changes, i.e., as new platforms emerge, new players join and existing players adapt their strategies, so do the incentives to both become active and influential on social media platforms. As a consequence, some of the more negative developments we have witnessed in the past, may intensify in the near future. The 2021 election in Germany provides another opportunity to study politicians and voters social media behavior during an election. 


\section{Appendix}

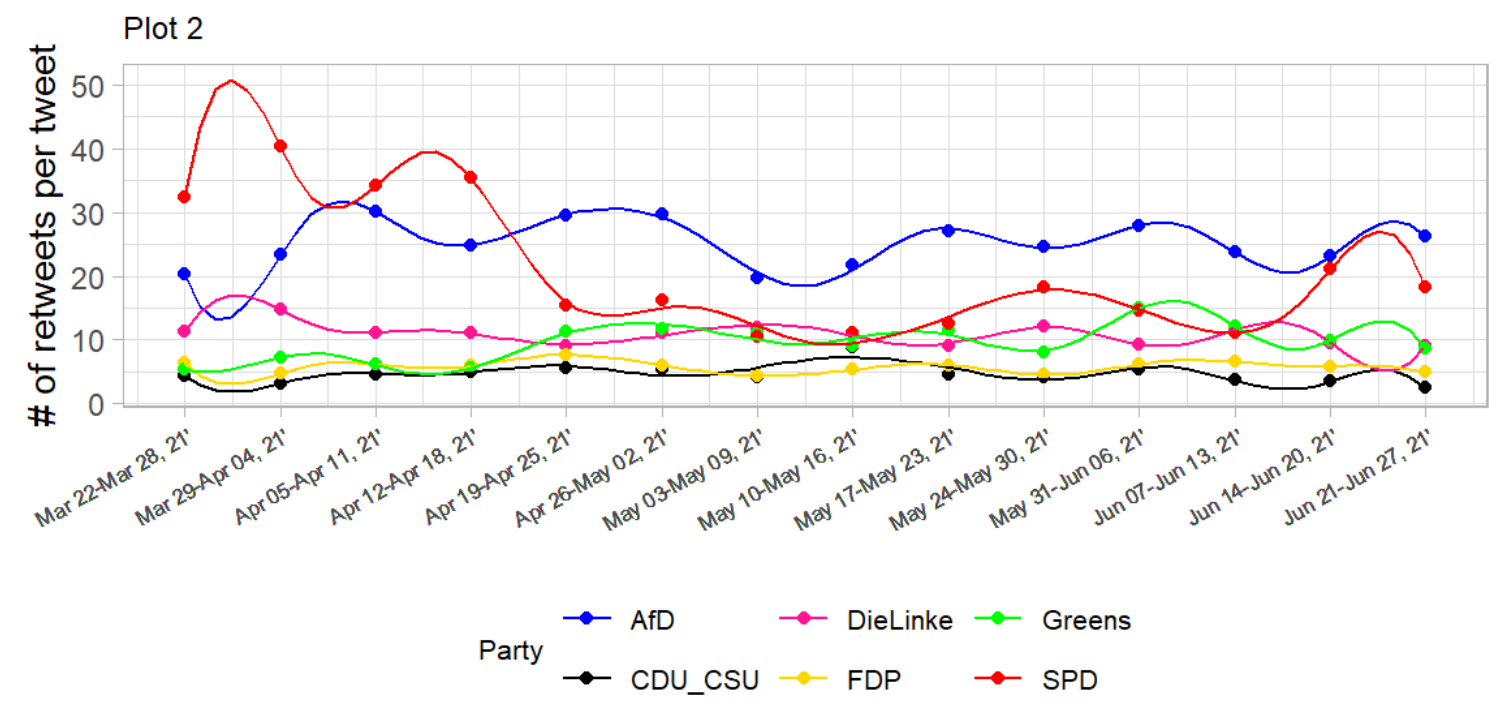

Figure 5.1: Retweets per tweet across party member accounts and weeks (without Lauterbach)

\section{References}

Bakshy E, Hofman JM, Mason WA, Watts DJ (2011). "Everyone's an Influencer: Quantifying Influence on Twitter." In Proceedings of the fourth ACM international conference on web search and data mining 65-74. ACM, New York, NY, USA.

Bastos MT, Mercea D (2019). "The Brexit Botnet and User-Generated Hyperpartisan News." Soc. Sci. Comput. Rev., 37(1), 38-54.

Brazell A (2008, October). "House Relents on New Media, Adopts Updated Rules for Web Video." https://www.technosailor.com/2008/10/02/house-relents-on-new-media-adopts-updated-rules -for-web-video/.

Brin S, Page L (1998). "The Anatomy of a Large-Scale Hypertextual Web Search Engine." Computer Networks and ISDN Systems, 30(1), 107-117.

Cha M, Haddadi H, Benevenuto F, Gummadi KP (2010). "Measuring User Influence in Twitter: The Million Follower Fallacy." In Fourth international AAAI conference on weblogs and social media. aaai.org.

Diehl J, Lehberger R, Müller A-K, Seibt P (2019, April). "Facebook Frenzy: How the German Right Wing Dominates Social Media - SPIEGEL ONLINE - International." https://www.spiegel.de /international/germany/germany-afd-populists-dominate-on-facebook-a-1264933.html; SPIEGEL ONLINE.

Evans HK, Cordova V, Sipole S (2014). "Twitter Style: An Analysis of How House Candidates Used Twitter in Their 2012 Campaigns." PS Polit. Sci. Polit., 47(2), 454-462. 
Gelman J, Wilson SL, Petrarca CS (2019, June). Mixing Messages: How Candidates Vary in Their Use of Twitter.

Golbeck J, Grimes JM, Rogers A (2010). "Twitter Use by the US Congress." J. Am. Soc. Inf. Sci. Technol., 61(8), 1612-1621.

Graham T, Jackson D, Broersma M (2018). "The Personal in the Political on Twitter: Towards a Typology of Politicians' Personalized Tweeting Behaviours." In Managing democracy in the digital age 137-157. Springer.

Grant WJ, Moon B, Busby Grant J (2010). "Digital Dialogue? Australian Politicians' Use of the Social Network Tool Twitter." Aust. J. Polit. Sci., 45(4), 579-604.

Hemphill L, Otterbacher J, Shapiro M (2013). "What's Congress Doing on Twitter?" In Proceedings of the 2013 conference on computer supported cooperative work 877-886. ACM, New York, NY, USA.

Hindman M (2008). "The Myth of Digital Democracy."

Hindman M, Barash V (2018). "Disinformation, and Influence Campaigns on Twitter."

Howard PN, Bolsover G, Kollanyi B, Bradshaw S, others (2017). "Junk News and Bots During the US Election: What Were Michigan Voters Sharing over Twitter.".Wpengine.netdna-Cdn.com,

Howard PN, Kollanyi B (2016, June). Bots, \#Strongerin, and \#Brexit: Computational Propaganda During the UK-EU Referendum.

Jungherr A (2016). "Twitter Use in Election Campaigns: A Systematic Literature Review." Journal of Information Technology \& Politics, 13(1), 72-91.

Jürgens P, Jungherr A (2015). "The Use of Twitter During the 2009 German National Election." Ger. Polit., 24(4), 469-490.

Kleinberg JM (2011). "Authoritative Sources in a Hyperlinked Environment." The Structure and Dynamics of Networks.

Kwak H, Lee C, Park H, Moon S (2010). "What Is Twitter, a Social Network or a News Media?" In Proceedings of the 19th international conference on world wide web 591-600. AcM; dl.acm.org.

Larsson AO, Kalsnes B (2014). "'Of Course We Are on Facebook': Use and Non-Use of Social Media Among Swedish and Norwegian Politicians." Eur J Commun, 29(6), 653-667.

McGregor SC (2019). "Why Twitter's Ban on Political Ads Isn't as Good as It Sounds." The Guardian,

Meeks L (2018). "Tweeted, Deleted: Theoretical, Methodological, and Ethical Considerations for Examining Politicians' Deleted Tweets." Inf. Commun. Soc., 21(1), 1-13.

Moon SJ, Hadley P (2014). "Routinizing a New Technology in the Newsroom: Twitter as a News Source in Mainstream Media." J. Broadcast. Electron. Media, 58(2), 289-305. 
Morozov E (2011). The Net Delusion: How Not to Liberate the World. Penguin UK.

Neudert L-M, Kollanyi B, Howard PN (2017). "Junk News and Bots During the German Parliamentary Election: What Are German Voters Sharing over Twitter?"

Nulty P, Theocharis Y, Popa SA, Parnet O, Benoit K (2016). "Social Media and Political Communication in the 2014 Elections to the European Parliament." Elect. Stud., 44, 429-444.

Paulussen S, Harder RA (2014). "Social Media References in Newspapers: Facebook, Twitter and YouTube as Sources in Newspaper Journalism." Journalism Practice, 8(5), 542-551.

Petrarca CS, Tyrberg M, Wilson SL (2019). "The 2018 Swedish Election Campaign on Twitter." Statsvetenskaplig Tidskrift, 121(3).

Quinlan S, Gummer T, Roßmann J, Wolf C (2018a). "'Show Me the Money and the Party!' Variation in Facebook and Twitter Adoption by Politicians." Inf. Commun. Soc., 21(8), 10311049.

Quinlan S, Gummer T, Roßmann J, Wolf C (2018b). "'Show Me the Money and the Party!' Variation in Facebook and Twitter Adoption by Politicians." Inf. Commun. Soc., 21(8), 10311049.

Roth M, Peters G, Seruga J (2014). "Tweeting Politicians: An Analysis of the Usage of a Micro Blogging System." In Enterprise information systems 351-365. Springer International Publishing.

Serrano JCM, Shahrezaye M, Papakyriakopoulos O, Hegelich S (2019). "The Rise of Germany's AfD: A Social Media Analysis." In Proceedings of the 10th international conference on social media and society 214-223. ACM, New York, NY, USA.

Suh B, Hong L, Pirolli P, Chi EH (2010). "Want to Be Retweeted? Large Scale Analytics on Factors Impacting Retweet in Twitter Network." In 2010 IEEE second international conference on social computing $177-184$. ieeexplore.ieee.org.

Syal R, Sabbagh D (2020). "Tory Whips Apologise for Urging MPs to Support Dominic Cummings." The Guardian,

Thimm C, Einspänner-Pflock J, Anastasiadis M (2016). "9. Twitter During the 2014 European Elections in Germany-Analyzing Politicians' Campaigning Strategies." Tweets from the Campaign Trail, 197.

Tucker JA, Theocharis Y, Roberts ME, Barberá P (2017). "From Liberation to Turmoil: Social Media and Democracy." Journal of Democracy, 28(4), 46-59.

Tucker JA, Theocharis Y, Roberts ME, Barberá P (2017). "From Liberation to Turmoil: Social Media And Democracy." Journal of Democracy, 28(4), 46-59. Retrieved from https://muse.jhu .edu/article/671987

Weng J, Lim E-P, Jiang J, He Q (2010). "TwitterRank: Finding Topic-Sensitive Influential Twitterers." In Proceedings of the third ACM international conference on web search and data mining 261-270. ACM, New York, NY, USA. 